\title{
Environmental And Socio-Economic Effects Of Timber Exploitation In Imo River Estuary, Eastern Obolo, Akwa Ibom State, Nigeria
}

\author{
Ebong, Mbuotidem Sampson*1, Victory Udoh ${ }^{1}$, Nsidibe Mbuotidem Sampson ${ }^{1}$, Comfort \\ Abraham ${ }^{1}$, Joseph Ogbobula ${ }^{1}$ \\ 1Department of Geography and Natural Resources, University of Uyo, Nigeria.
}

\begin{abstract}
Purpose: This study was carried out to evaluate the environmental and socio-economic effects of timber harvesting as well as to identify the drivers increasing the rate of timber exploitation in Imo River Estuary, Eastern Obolo Local Government Area, Akwa Ibom state, Nigeria.

Methodology: It was conducted in five Local Government Areas (LGAs) in Eastern Obolo Local Government Area, Akwa Ibom state, Nigeria. A random sampling technique was employed to select a total of 300 respondents composed of 60 randomly selected respondents from each of the five LGAs. A structured questionnaire was used in collecting information from the respondents. Data acquired from the field was subjected to statistical and econometric analysis which included percentages, frequencies, Likert scale rating, exploratory factor analysis, and Chi-square,

Main Findings: The major finding of this study was that the major cause of timber exploitation in the study area was unemployment, absence of forest regulations, unstable government policies, lack of trained officials, and high cost of timber products. The application of the Factor Analysis Model in this study showed that loss of biodiversity, the disappearance of forest cover, damaging of immature trees and non-wood forest products are the highest environmental effects of timber exploitation in the study area, loading far higher than the stated 0.3 decision score value. Among the social effects, high cost of farm labor is the most severe of social effects in the study area, while the increased cost of wood and forest product and high cost of living ranked highest among the economic effects.

Applications: The study will be of great importance to environmental policy makers, conservationists, researchers, and Geographers in Nigeria. It will contribute significantly to knowledge build-up in relation to restoring the sanctity of threatened forests in Southern Nigeria.

Novelty/Originality: The Niger Delta region of Nigeria where this study was carried out is often synonymous with militancy and the problems of environmental pollution. However, this study veers from these already known challenges to peculiar drivers of the depleting forests in this area. The study, therefore, will contribute to the scanty literature related to the subject matter within the study area.
\end{abstract}

Keywords: Socio-Economic, Imo River Estuary, Environment, Harvesting, Social, Timber.

\section{INTRODUCTION}

Forests cover almost $25 \%$ of the worlds land and are critical in meeting human needs for water, food, shelter, medicine, fuelwood, fodder and timber. They also provide a wide range of environmental services which mainly include biodiversity conservation, watershed protection, protection of soil, mitigation of global climate change, etc. (Hirakuri, 2013; Landell-Mills \& Porras, 2012). Although other resources from the natural environment have been exploited; the rate of timber harvesting has accelerated significantly since the turn of the century. In the last several decades, deforestation and biodiversity loss became a common event throughout the globe. This phenomenon is much more frequent in developing countries like Nigeria. According to FAO (2012), the world has just less than 4 billion hectares of forest, covering about $20 \%$ of the worlds land area and a large area of land converted from its original vegetation cover to cropping. Surprisingly, the net forest loss remains 7.3 million hectares per year or 20,000 ha per day (Ajake and Enang, 2012). This is most serious in the tropics where over 2.5 billion people depend on the natural forest resources for variety of services (Butler, 2012), in which Putz (2011) maintained that the major causes of lumbering are increasing demand for housing and infrastructural facilities, timber export, poor agricultural practices, cutting of fuelwood for urban areas, head loading (cutting of fuelwood for sale), forest fires, logging, overharvesting.

\footnotetext{
${ }^{1}$ Corresponding Author: mbuotisampson@gmail.com
} 
One difficult task faced by both developed and developing countries is how to guarantee sustainable utilization of natural resources especially timber at the lowest possible environmental cost, while still ensuring both economic and social development (Klawitter, 2014). Of late as a signatory of various regional and international conventions, treaties and protocol government has taken various initiatives to address the situation and to ensure the conservation of remaining floral and faunal diversity (Brown and Durst, 2013). This work therefore seeks to investigate on the environmental, economic and social effects of timber exploitation in Akwa Ibom state, using Imo river estuary as a case study, whereby, a proper understanding of resources-environment linkage is a good approach in developing effective public policy in retrospect to the myriads of harm that have been wittingly done to the ever-diminishing timber resources, in the same vein still observing environmental sustainability. Thus, the aims of this study entail: (i) To identify and classify the forms of vegetation exploited for timber in the study area, (ii) To identify the major drivers of timber exploitation in the area, (iii) To identify the major environmental, economic and social effects of timber exploitation in the study area.

\section{LITERATURE REVIEW}

\section{Drivers of Timber Exploitation}

Through history, the fates of the world's forest have strongly reflected the pattern and intensity of land use by societies. Demand for agricultural land, timber, and other forest products, as well as technological change in agriculture, significantly impacts the mode and rate of transformation of forested areas. According to the World Resources Institute (WRI), the world has lost about half of its forest cover from 62 million $\mathrm{km}^{2}$ to 33 million $\mathrm{km}^{2}$ (Summerlin et al., 2015). The magnitude of the global biodiversity situation is undoubtedly threatened a million times higher than any time of its history. Over 15 million hectares of natural forest are lost in the tropics every year which is more than the area of Nepal or Arkansas in the United States (FAO, 2009), also the present rate of species extinction is estimated to be between 1000 and 10,000 times the historical (pre 10,000 years BP) rate (Belcher, Achdiawan, \& Dewi, 2015; Wilson, 2008), thereby, the struggle to save the forest continues and there is a growing worldwide concern about deforestation.

Thus, the proximate or direct drivers of forest exploitation/deforestation and Forest degradation are human activities and actions that directly impact forest cover and result in loss of carbon stocks. The direct drivers of such biodiversity loss especially forest resources include: agriculture (food crops and livestock), which remains the largest direct human-induced driver of biodiversity degradation, species loss, and conversation of natural habitat (Díaz, Fargione, Chapin III, \& Tilman, 2006); while others include mining, population growth/urban expansion and infrastructural development as well as overexploitation of forest resources. Underlying drivers consist of an interplay of economic, technological, institutional and sociocultural factors (Geist and Lambin, 2012). In which many well-known indirect drivers of forest exploitation exist, causing the subsequent loss of forest over time, such underlying factors lies many indirect drivers which include; the governance of land use change, poverty, illiteracy, and land tenure security.

\section{Implications of Timber Exploitation}

Drivers of change in biodiversity may be natural or human-induced. Many human interventions in ecosystems generate abrupt and large-scale changes that trigger a loss of biodiversity and make it more difficult for ecosystems to recover from the negative impacts associated with these human interventions. Ecosystem recovery from such human-induced change is not only slow and costly in some cases, but the ecosystem may also be irreversible (Díaz et al., 2006). This study focuses on human-induced changes in forest biomes. Since these may differ according to geographical location and factors involved, it is impossible to discuss all possible variations. Thus, forest exploitation at the study area has tremendously threatened to deplete or endangered biodiversity in the forest ecosystem, having negative ecological, genetic and socio-economic effects on the environment. Its implications, therefore, include:

i) Atmospheric Pollution: It was noted that forest exploitation in developing countries is held to account for about $18 \%$ to $30 \%$ of increased emissions of greenhouse gases (GHG), which are responsible for global warming and climate change (Owusu, Nketiah and Aggrey, 2011). Trees serve as a carbon sink, by absorbing Carbon dioxide, Co2. Trees and other plants remove carbon in the form of carbon dioxide from the atmosphere during the process of photosynthesis. Carbon dioxide is dangerous to animals including man and as deforestation takes place, the few trees left cannot absorb a huge amount of carbon dioxide, therefore, the excess carbon dioxide gets into the atmosphere causing global warming.

ii) Loss of Biodiversity and Habitat Destruction: Forest houses half of the world's animals such as mammals, reptiles, insects and invertebrates. Most of them are hardly found on the ground because trees provide food and 
shelter for them. Several plants and assorted animals have been depleted while some are endangered and lost as the next generation may not be aware of such occurrences. For instance, several plant species have been overexploited especially those with edible fruits, seeds, vegetables, roots, trees, mushrooms, culinary plants, medical plants, nuts, and kernels. Also, most primates such as chimpanzee, gorilla, monkeys, reptiles, chameleon, amphibians and birds, among others are being endangered (Akachukwu, 2015). These lost plants and animals are of economic importance such as food, medicine, hides, and others. In the study area, loss of biodiversity due to forest exploitation activities such as logging and unsustainable collection of non-timber forest products are posing a serious threat to forest conservation in the study area. According to Valente, Spinelli, and Hillring (2011) many species in the environment are threatened due to loss and fragmentation of habitat,over-exploitation, modification, and introduction of invasive species, such as Nypa palm species seen in the study area (Imo river estuary). Some wildlife species that existed 1020 years ago are now extinct in our forest land, such as it is very rare for some species of animals such as elephant, chimpanzee, lions, and gorilla to be seen or encountered in Akwa Ibom state (King and Udosen, 2010). Other eminent implications of timber exploitation are soil erosion, climate change, loss of forest products, depletion of water and soil resources, etc.

\section{METHOD OF DATA ANALYSIS}

Data for the study were collected from primary source only. This was done using a set of structured and pre-tested questionnaire. In order to realize the specific objectives of the study, relevant analytical tools were employed. Descriptive statistics such as frequency, percentage, tables, and charts were used to realize objectives (i). The Likert scale rating technique was used to realize objective (ii), while the principal component factor analysis model was used to realize the objective.

\section{Model Specification}

A five-point Likert-type rating scale was used in this work as applied by Agbo, Onyenekwe, and Obasi (2015) based on their study on sustainable timber utilization and management, but they used a four-point Likert-scale rating. This technique was used in this work for determining objective (ii) which entails the causes or drivers of timber exploitation. The scaling was regarded as; Strongly Agree (SA), Agree (A), Undecided (U), Disagree (D), Strongly Disagree (SD) or other similar ratings with corresponding values of 5, 4, 3, 2 and 1 respectively.

The mean score of respondents based on a 5 -point rating scale was computed as;

$=5+4+3+2+1$

$=155$

$=3.00$ (cut off point).

Using the interval scale of 0.05 , the upper cut-off point was $3.00+0.05=3.05$ while the lower limit cut-off was $3.00-0.05=2.95$. Based on this, any item means score below 2.95 was taken as Strongly Disagree or Disagree as the case may be, while those items with mean values between 2.95 and 3.05 were considered as Undecided, while items with mean values above 3.05 were considered as Strongly Agree or Agree as the case may be.

Item Mean Score $=$ EE Rating score $\times$ No of respondents for the score

Total number of respondents

\section{Factor analysis model}

This was employed to analyze the effects of timber exploitation on the natural environment and the socio-economic well-being of the people. The dependent variable here was environmental, economic and social effects of timber exploited, while the causal factors will be the independent variables.

The principal component factor analysis model was used in achieving the objective (iii). It was stated as follows:

$\mathrm{Y} 1=\mathrm{a} 11 \mathrm{x} 1+\mathrm{a} 12 \mathrm{x} 2+\ldots \ldots \ldots \ldots+\mathrm{a} 1 \mathrm{n} \mathrm{xn}$
$\mathrm{Y} 2=\mathrm{a} 21 \mathrm{x} 1+\mathrm{a} 12 \mathrm{x} 2+\ldots \ldots \ldots \ldots \ldots+\mathrm{a} 2 \mathrm{n} \times \mathrm{xn}$
$\mathrm{Yn}=\mathrm{a} 1 \mathrm{x}+\mathrm{an} 2 \mathrm{x} 2+\ldots \ldots \ldots \ldots \ldots+\mathrm{ann} \mathrm{xn}$

Where:

Y1, Y2 ......... $\mathrm{Yn}=$ Observed variable or consequences of timber harvesting;

a1 - an $=$ Factor loading or correlation coefficients, and 
$\mathrm{X} 1, \mathrm{x} 2 \ldots \ldots . . \mathrm{xn}=$ unobserved underlying factors or consequences of timber harvesting.

\section{RESULTS}

Table 1: Respondents' View on the Most Exploited Vegetation

\begin{tabular}{lcc}
\hline Vegetation Type & Frequency & Percentage (\%) \\
\hline Mangrove forest & 80 & 26.67 \\
Freshwater swamp forest & 65 & 21.68 \\
Tropical rainforest & 155 & 51.67 \\
Total & 300 & 100 \\
\hline
\end{tabular}

Source: Researcher's Field Work, 2017.

Table 2: Respondents' Perception of the Drivers of Timber Exploitation.

\begin{tabular}{|c|c|c|c|c|c|c|c|c|c|c|c|c|c|}
\hline $\begin{array}{l}\text { Drivers of } \\
\text { timber } \\
\text { exploitatio } \\
\text { n }\end{array}$ & $\begin{array}{l}\text { Stro } \\
\text { ngly } \\
\text { Agre } \\
\text { e } \\
\text { (SA) }\end{array}$ & $\begin{array}{l}\text { Agree } \\
\text { (A) }\end{array}$ & $\begin{array}{l}\text { Unde } \\
\text { cided } \\
\text { (UN) }\end{array}$ & $\begin{array}{l}\text { Disagr } \\
\text { ee (D) }\end{array}$ & $\begin{array}{l}\text { Stron } \\
\text { gly } \\
\text { Disag } \\
\text { ree } \\
\text { (SA) }\end{array}$ & Total & $\begin{array}{l}\text { Item } \\
\text { Mean } \\
\text { Score }\end{array}$ & $\begin{array}{l}\text { Re } \\
\text { ma } \\
\text { rk }\end{array}$ & $\mathbf{S A}$ & $\mathbf{A}$ & $\mathbf{U N}$ & D & SD \\
\hline $\begin{array}{l}\text { Poverty } \\
\text { and hunger }\end{array}$ & 10 & 50 & 30 & 70 & 140 & 300 & 2.04 & $\mathrm{SD}$ & 3.3 & 16.6 & 10.0 & $\begin{array}{l}23 . \\
3\end{array}$ & 46.6 \\
\hline $\begin{array}{l}\text { Absence of } \\
\text { forest } \\
\text { regulations }\end{array}$ & 60 & 160 & 40 & 20 & 20 & 300 & 3.72 & A & 20.0 & 53.3 & 13.3 & 6.6 & 6.6 \\
\hline $\begin{array}{l}\text { High cost } \\
\text { of timber } \\
\text { products }\end{array}$ & 160 & 60 & 35 & 25 & 20 & 300 & 4.03 & SA & 53.3 & 20.0 & 11.6 & 8.3 & 6.6 \\
\hline $\begin{array}{l}\text { High cost } \\
\text { of timber } \\
\text { products }\end{array}$ & 150 & 55 & 25 & 70 & 0 & 300 & 3.94 & $\mathrm{~A}$ & 50.0 & 18.3 & 8.3 & $\begin{array}{l}23 . \\
3\end{array}$ & 0.0 \\
\hline $\begin{array}{l}\text { Expanding } \\
\text { agriculture }\end{array}$ & 15 & 50 & 80 & 50 & 105 & 300 & 2.39 & $\mathrm{D}$ & 5.0 & 16.6 & 26.6 & $\begin{array}{l}16 . \\
6\end{array}$ & 35.0 \\
\hline $\begin{array}{l}\text { Inadequacy } \\
\text { of } \\
\text { farmland }\end{array}$ & 5 & 25 & 55 & 95 & 120 & 300 & 1.99 & $\mathrm{SD}$ & 1.6 & 8.3 & 18.3 & $\begin{array}{l}31 . \\
6\end{array}$ & 40.0 \\
\hline Illiteracy & 10 & 40 & 35 & 85 & 130 & 300 & 2.03 & SD & 3.3 & 13.3 & 11.6 & $\begin{array}{l}28 . \\
3\end{array}$ & 43.3 \\
\hline Corruption & 40 & 50 & 110 & 45 & 55 & 300 & 2.95 & UN & 13.3 & 16.6 & 36.6 & $\begin{array}{l}15 . \\
0\end{array}$ & 18.3 \\
\hline $\begin{array}{l}\text { Expanding } \\
\text { Population }\end{array}$ & 45 & 65 & 105 & 55 & 30 & 300 & 3.12 & A & 15.0 & 21.6 & 35.0 & $\begin{array}{l}18 . \\
3\end{array}$ & 10.0 \\
\hline $\begin{array}{l}\text { Rapid } \\
\text { urbanizatio } \\
n\end{array}$ & 35 & 50 & 120 & 60 & 35 & 300 & 2.96 & UN & 11.6 & 16.6 & 40.0 & $\begin{array}{l}20 . \\
0\end{array}$ & 11.6 \\
\hline $\begin{array}{l}\text { Lack of } \\
\text { trained }\end{array}$ & 140 & 95 & 55 & 15 & 10 & 300 & 4.27 & SA & 46.6 & 31.6 & 18.3 & 5.0 & 3.3 \\
\hline
\end{tabular}


officials

\begin{tabular}{lccccccccccccc}
$\begin{array}{l}\text { Unstable } \\
\text { governmen } \\
\text { t policies }\end{array}$ & 155 & 85 & 40 & 10 & 10 & 300 & 4.20 & SA & 51.6 & 28.3 & 13.3 & 3.3 & 3.3 \\
$\begin{array}{l}\text { Livestock } \\
\text { grazing }\end{array}$ & 0 & 20 & 35 & 90 & 155 & 300 & 1.72 & SD & 0.0 & 6.6 & 11.6 & 30. & 51.6 \\
$\begin{array}{l}\text { Unemploy } \\
\text { ment }\end{array}$ & 195 & 80 & 15 & 5 & 5 & 300 & 4.50 & SA & 65.0 & 26.6 & 5.0 & 1.6 & 1.6 \\
\hline
\end{tabular}

Source: Researcher's Field Work, 2017.

Table 3: Environmental, Economic and Social Effects of Timber Exploitation (Factor analysis table)

\begin{tabular}{|c|c|c|c|}
\hline \multirow[t]{3}{*}{ Variables } & \multicolumn{3}{|c|}{ Factors } \\
\hline & Environmental & Social Effect & Economic \\
\hline & $\begin{array}{l}\text { Effect (Factor } \\
\text { one) }\end{array}$ & (Factor two) & $\begin{array}{l}\text { Effect (Factor } \\
\text { three) }\end{array}$ \\
\hline Silting of rivers and lakes & .707 & .129 & -.245 \\
\hline High cost of farm labor & -.021 & 697 & -.159 \\
\hline Occurrence of dispute and crises over land \& compensation & -.201 & .655 & -.102 \\
\hline Damaging of immature trees and non-wood forest products & .596 & -.363 & -.491 \\
\hline Loss of income and revenue by government & -.231 & .887 & -.045 \\
\hline Reduction in soil fertility and crop output & .817 & -.139 & .441 \\
\hline Loss of biodiversity & .956 & -.044 & -.694 \\
\hline Loss of forest land & .282 & -.175 & .638 \\
\hline Disappearance of forest cover & .193 & .436 & .315 \\
\hline Rural urban migration & .513 & -.152 & -.384 \\
\hline High cost of living & .305 & -.164 & .856 \\
\hline The increased cost of wood and timber products & .305 & -.174 & -.865 \\
\hline Climate change/global warming & .385 & -.513 & -.424 \\
\hline Soil erosion & .554 & -.283 & -.004 \\
\hline
\end{tabular}

Extraction Method: Exploratory Factor Analysis

Source: Researcher's Field Work, 2017

\section{DISCUSSION OF FINDINGS}

Table 1 shows that based on the view of the respondents, the rate of exploitation in the mangrove forest is $26.67 \%$, in freshwater swamp forest $21.67 \%$ and in tropical rainforest $51.67 \%$. This implies that the tropical rainforest is the most exploited vegetation and that timber is threatened in this vegetation found in the study area, other wood species are also exploited in the mangrove and freshwater swamp forest.

Table 2 above represents a summary of the perception of respondents on the causes of timber exploitation. From the result, $46.6 \%$ strongly disagreed that poverty and hunger among the inhabitants of the study area was a driver of timber exploitation. With respect to the absence of forest regulations, $53.3 \%$ of the respondents agreed that it was a cause of timber exploitation, whereas about $10.0 \%$ of the respondents disagreed while about $13.3 \%$ of the respondents were indecisive. The majority being $53.3 \% \& 51.6 \%$ of the respondents strongly agreed that high cost of timber products and unstable government policies respectively, had been very serious drivers that have over the years spawned timber exploitation in the study area.

Also, high cost of alternative wood products and lack of trained officials in the areas of timber exploitation were admitted to be major causes of uncontrolled timber harvesting in the study area, as strongly agreed by $50.0 \%$ \& 46.6\% respectively. This is comparable with the findings of Agbo et al (2015) using Ebonyi state as a case study, it was confirmed that high cost of timber products, absence of forest regulations, high cost of alternative wood products were very serious factors that generated to excess exploitation of timber in the study area.

Unemployment was one of the most serious driving forces of timber harvesting since $65.0 \%$ of respondents strongly agreed that it was a severe driver of trees felling/illegal logging. Rapid urbanization, expanding population and corruption recorded that $40.0 \%, 35.0 \% \& 36.6 \%$ of the respondents respectively were indecisive about these factors 
being causes of timber exploitation in the study area, although $16.6 \%, 21.6 \% \& 16.6 \%$ of the respondents respectively agreed that they were causes of timber exploitation in the study area.

The factors strongly disagreed on by $51.6 \%, 35.0 \%, 40.0 \%$ \& $43.3 \%$ of the respondents interviewed were, livestock grazing, illiteracy, inadequacy of farmlands, and expanding agriculture respectively, in which $30.0 \%, 28.3 \%, 31.6 \%$ \& $26.6 \%$ of the respondents respectively also further confirmed these factors as not serious causes of timber exploitation in the study area.

From Table 3 above, the results obtained from the exploratory factor analysis, taking 0.3 as a decision score, factors that loaded from 0.3 and above were noted to be areas of significant effects, while factors that loaded below 0.3 were noted to have a less significant effect and as such were ignored. that Silting of rivers and lake (0.207), damaging of immature trees and non-forest wood products (0.596), reduction in soil fertility and crop output $(0.817)$, loss of biodiversity (0.956), disappearance of forest cover (0.913), rural-urban migration (0.512), increased cost of wood and forest products $(0.305)$, climate change and global warming $(0.385)$ and soil erosion $(0.554)$ loaded above 0.3 in the first factor (environmental) implying that they all have affected the environment of the study area negatively. Thus, this shows over-dependence on timber resources as well as other present forest resources by the rural dwellers resulting in scanty forest vegetation and poor forest sustainability. This concurs with Agbo et al (2015), who opined that excess reliance of the locals of timber resources results in a heavy decline in the functioning of the forests' ecosystem.

In the same vein, taking the social effects into consideration, High cost of farm labour (0.697), occurrences of dispute and crises over land and compensation (0.655) as occurrences between two villages Amadaka and Elile in the study area, loss of income and revenue by government (0.387), disappearance of forest cover $(0.436)$ and high cost of living (0.466), all have social effects in the study area. Also the effects that loaded high under Factor three (economic effect) are: reduction in soil fertility and crop output (0.441), loss of forest land (0.638), high cost of living (0.783), increased cost of wood and forest products $(0.856)$; meaning that they have a high effect on the economy of the study area. Hence, these result from the analysis has shown factors that are affecting the environmental, economic and social well-being of the study area.

\section{CONCLUSION}

This study investigated the effects of timber exploitation in Eastern Obolo LGA segment of the Imo river estuary, revealing that timber harvesting affects the environmental, economic and social well-being of the inhabitants of the study area. These effects are caused by the following human activities which result in timber exploitation; unemployment, high cost of timber products, unstable government policies, lack of trained officials, poverty \& hunger, absence of forest regulations and high cost of alternative wood products, rapid urbanization, expanding population, illiteracy, and corruption. Furthermore, most of the effects of timber exploitation are quite obvious such as increased cost of wood \& timber products, occurrence of dispute and crises over land \& compensation, damaging of immature trees \& non-wood forest products, loss of forest land, etc.; compared to others like the much pronounced climate change/global warming and extinction of species which are likely to manifest soon in the study area. Also, another danger posed by uncontrolled/illegal logging is that it has been used as tools to sponsor conflicts between two or more communities such as occurred between these two villages Amadaka and Elile. Hence, a wholistic approach to resource management and sustainability is of eminent essence to ensure a balanced ecosystem and long-term availability of natural resources for the present and future generations.

\section{RECOMMENDATIONS}

This study suggests the following recommendations:

(i) The ministry of agriculture and other related stakeholders should adequately sensitize the public on the long-term implications of illegal logging on the environment and socio-economic well-being of inhabitants of the concerned communities.

(ii) State government and logging companies should embark on reforestation, afforestation and regeneration programs, in order to replace extracted tree species and regenerate extinct species.

(iii) The government should ensure that all logging companies and cooperative bodies and private individuals must acquire and tender their certification and license before gaining access to the forest and its resources.

(iv) Apt laws and penalties should be established to curb incessant cutting down of trees and erring person should be sanctioned.

\section{REFERENCES}


Agbo, F. U., Onyenekwe, S. C., \& Obasi, F. A. (2015). Sustainable timber utilization and management in Ebonyi State, Nigeria. African Journal of Agricultural Research, 10(19), 2061-2067.

Ajake, A. O, and Enang, E. E, (2012). Demographic and socio-economic attributes affecting forest ecosystem exploitation and management in the rural communities of Cross River State, Nigeria, Am. Int. J. Contemp. Res. 2(1): 174-184.

Akachukwu, A. C., (2015), Disappearing Forests: The Consequences and Challenges of Sustainable Development in Nigeria, In Proceedings of 31st Annual Conference of the Forestry Association of Nigeria held in Markurdi, Benue state, Nigeria, 20th-25th November 2006, Pp 48-61.

Belcher, B., Achdiawan, R., \& Dewi, S. (2015). Forest-based livelihoods strategies conditioned by market remoteness and forest proximity in Jharkhand, India. World development, 66, 269-279.

Brown, C., Durst, P. B., \& Asia-Pacific Forestry Commission. (2003). State of forestry in Asia and the Pacific, 2003. Status, changes and trends.

Butler, R. (2012), How to save tropical rainforest. Retrieved 2016 from http://rainforest.mongbay.com/1001/.htm

Díaz, S., Fargione, J., Chapin III, F. S., \& Tilman, D. (2006). Biodiversity loss threatens human well-being. PLoS biology, 4(8), e277.

FAO (2009), Situacion de Los basques del Munro. 2009, FAO, Rome, Italy.

FAO (2012): Forestry Resource Assessment, and the State of World's Forest, FAO: Rome, Italy.

Geist, H., and Lambin, E., (2012), What drives tropical deforestation? A meta-analysis of proximate and underlying causes of deforestation based on substantial case study evidence. Land Use and Land Cover Change (LUCC), Report series 4, Louvain LA Neuve, Belgium, International Geosphere Biosphere Programme $(I G B P) . h t t p / / w w w . p i k-p o s t d a m . d e / \sim l u e d e k e / l u c c 4 . p d f)$, Pp 1-116.

Hirakuri, S. R, (2013), Can Law save the forests? Lessons from Finland and Brazil, CIFOR, Bogor, Indonesia, 2(51), Pp1-120.

King, E. J and Udosen, E. O (2010), Deforestation in Akwa Ibom state: Causes, Impact and Solutions in Forestry and Sustainable environment. 1st Workshop of Forestry Association of Nigeria, Akwa Ibom state branch, April 2001.

Klawitter, S., (2014), China's Agenda 21, White paper on China's population, Environment and Development in 21 st Century, Environmental Policy Research Center, Innestr. 22, 14-915.

Berlin Landell-Mills, N and Press, I. T, (2012), Silver bullet or fools' gold? A global review of markets for forest environmental services and their impact on the poor. IIED, london. 7(11) 1-254.

Owusu, B., Nketiah, K. S and Aggrey, J., (2011) Combating unacceptable forest practices in Ghana, Trompenbos International, Ghana, Policy brief, September 2011. 1-20.

Putz, F. E, (2011), Tropical Forest Management and Conservation of Biodiversity: An overview. Conserv. Biol. 15: 7-20.

Summerlin, N., Soo, E., Thakur, S., Qu, Z., Jambhrunkar, S., \& Popat, A. (2015). Resveratrol nanoformulations: challenges and opportunities. International journal of pharmaceutics, 479(2), 282-290.

Sunderlin, W. D, Angelsen, A., Belcher, B., Burgers, P., Nasi, R., Santoso,L and Wunder, S., (2015), Livelihoods, forest and conservation in developing countries : An overview. World Development 33 (9): 1383-1402.

Valente, C., Spinelli, R., \& Hillring, B. G. (2011). LCA of environmental and socio-economic impacts related to wood energy production in alpine conditions: Valle di Fiemme (Italy). Journal of Cleaner Production, 19(17-18), 1931-1938.

Wilson, S. (2008). Research is ceremony: Indigenous research methods. 